\title{
Adnominal possession: combining typological and second language perspectives
}

\section{Björn Hammarberg and Maria Koptjevskaja-Tamm}

\section{Introduction}

The notion of possession and its linguistic manifestations have been a popular topic in linguistic literature for a long time. What we will attempt here is to explore the domain of adnominal possession - possessive relations and their manifestations within the noun phrase - in one particular language from two combined points of view: the typological characteristics of the system, and the picture that emerges from second language learners' attempts to handle adnominal possession in production. We are focusing on Swedish, a language with a distinctive and rather elaborate system of adnominal possession. Our aim is twofold: to present an overview of how the Swedish system of adnominal possessive constructions works, and to show how acquisitional aspects connect with typological aspects in this domain.

The English phrases Peter's hat, my son and a boy's leg all exemplify prototypical cases of adnominal possession whereby one entity, the possessee, referred to by the head of the possessive noun phrase, is represented as possessed in one way or another by another entity, the possessor, referred to by the attribute. It has become a commonplace in linguistics that possession is a difficult, if not impossible, notion to grasp (for a survey of adnominal possession in a crosslinguistic perspective cf. Koptjevskaja-Tamm 2001). However, even though it seems impossible to give a reasonable general definition for all the meanings covered by possessive constructions across languages and even in one language, we can still provide criteria for identifying a possessive construction, or possessive constructions in a language. Our first semantic criterion for a possessive construction 
departs from the prototypical cases of adnominal possession - i.e., whether it can be used at all for referring to legal ownership (Peter's hat), or to kinship relations (my son) or to body-part relations ( $a$ boy's leg). Note that reference to just one of these relations to the exclusion of the other two will be fine - as is well known, a number of languages regularly employ different possessive constructions for reference to alienable possession (e.g. legal ownership) and to inalienable possession (e.g., kinship relations and/or body-part relations). According to our second, formal criterion, the possessor and the possessee in adnominal possession together form one NP, a possessive NP, or at least belong to one NP. Adnominal possession is, thus, opposed to at least two other related phenomena: predicative possession, such as Peter has a hat or The hat belongs to Peter (for a definition cf Heine 1997: 29-33), and external-possession constructions, in which a possessor "does not occur as a dependent constituent of the modified NP, but NP-externally as a constituent of the clause" (Haspelmath 1999a: 109), e.g. in Swedish Jag tittade honom $i$ ögonen 'I looked in his eyes', lit. 'I looked him in the eyes'. Finally, we will only be interested in the most common, unmarked, 'standard' means of building possessive constructions. For English, this means that we will exclude examples like the house which is in Peter's possession. On the other hand, Peter's school/dreams/wife or cat's plate, which hardly refer to possession stricto sensu, will all count as possessive NPs since they have the same structure as the typically possessive noun phrases such as Peter's hat/brother/leg.

By combining the two criteria we can identify the possessive adnominal constructions in a language, which together will constitute its domain of adnominal possession. Languages differ considerably in how many and what structural types of adnominal possessive constructions they have, and also how, according to what parameters the whole domain is stratified among these constructions. The first type of question has been particularly popular in cross-linguistic studies Ultan (1978); Seiler (1983); Croft (1990: 28-39); Plank (1995), Koptjevskaja-Tamm (forthc. a) all present structural classifications of adnominal possessive constructions. The second type of questions has also been approached cross-linguistically, particularly in the 
work by Seiler and linguists connected with the tradition of the Cologne typological school (Serzisko 1984; Lehmann 1998, to mention a few). Further, there are numerous publications (too many to be listed) dealing with possessive constructions in a single language, without relating it to other languages.

The connection between second language research and linguistic typology is not a new one. Early studies combining a multilingual description in a functional-typological framework with L2 error analysis made it clear that the typological properties of especially the target language can shed light on the nature of the acquisitional task, and, conversely, the L2 acquisitional aspect will highlight inherent properties of the languages involved, notably the target language (cf. e.g. Hammarberg and Viberg 1977). Studies applying the Greenbergian notion of markedness (cf. Greenberg 1966; Croft 1990) to second language acquisition have demonstrated learners' preference for adhering to unmarked linguistic structures (cf. Eckman 1977, 1996; Hyltenstam 1984, 1986, among others). There is a wide literature on linguistic universals and second language acquisition, both in functionalist and formal-generative frameworks.

Grammaticalisation is a further aspect which connects second language studies to typology. We should be careful here to keep apart two related, but different senses in which this term is used. It has been taken over into (first and second) language acquisition research from diachronic typology, where it is well established in the sense of a process which gradually develops grammatical elements and constructions in a language out of lexical material. In the second language acquisition literature, grammaticalisation has mostly come to refer to the emergence and development of learners' grammars (cf. Dittmar 1992; Perdue and Klein 1992; Pfaff 1992; Giacalone Ramat 1992; Skiba and Dittmar 1992). The connections between phylogenetic and ontogenetic domains of application and the similarities and differences in nature between diachronic-typological grammaticalisation and acquisitional grammaticalisation can be debated (for a discussion of the two notions, cf. Giacalone Ramat 1992: 297-300). But it is clear that the two perspectives have rather different implications for the understanding of what the second language learner is 
acquiring. In the present study we will refer to grammaticalisation in the diachronic-typological sense, unless we state otherwise.

In the following, we will first outline the system of adnominal possessive constructions in Swedish in section 2, then in section 3 analyse the main problems with adnominal possession encountered in L2 Swedish production, and finally in section 4 discuss the combined picture that emerges from these two approaches.

\section{Adnominal possessive constructions in Swedish}

\subsection{General}

In Modern Swedish, adnominal possession, as defined in section 1, is mainly expressed by three constructions:

- the "standard possessive noun phrase", in which the possessor precedes the possessee;

- noun-noun compounds, in which the first part modifies the second one; and

- constructions in which the head nominal is modified by a postposed prepositional phrase.

According to the semantic criterion, all these constructions are possessive: thus, both "standard possessive noun phrases" and nounnoun compounds can refer to both legal ownership, kinship relations and body-part relations, whereas constructions with postposed prepositional phrases can refer to kinship relations and to body-partrelations (although not to legal ownership). According to the formal criterion, the three constructions represent adnominal possession, since the possessor and the possessee belong to one and the same NP.

In the following subsections we will go through the main properties of these three construction types and the factors behind the choice among them. In the last subsection, we will present the typological profile of Swedish adnominal possession. 


\subsection{Standard possessive noun phrases}

In the "standard possessive noun phrase", abbreviated as PNP in the rest of this paper, the possessor adnominal precedes the possessee. The possessor is

- either a special possessive pronoun (for the first and second persons and reflexives) agreeing with the possessee in gender and number, cf. min bil 'my:COM car' vs. mitt bord 'my: $\mathrm{N}$ table' vs. mina bilar 'my:PL cars',

- or marked with the element $-s$ (these are normally referred to as "genitives"), cf. Peters bil/Peters bilar 'Peter's car/Peter's cars', hans bil/hans bilar 'his car/his cars'.

Morphosyntactically, the Swedish (and, generally, Standard Continental Scandinavian) possessive $-s$ behaves similarly to its English counterpart - 's. Thus, it always appears at the very end of a noun, after all suffixes, cf. en pojke-s 'a boy-GEN', pojke-n-s 'boyDEF.COM-GEN', pojk-ar-s 'boy-PL-GEN', pojk-ar-na-s 'boy-PLDEF.PL-GEN'. It also shows the tendency to attach to the final word of a NP resulting in what is traditionally called "group genitives", as in mannen på gatans åsikter - lit.'the man in the street's opinions' (i.e., an ordinary person's opinion). Its form is even more consistent than the form of -'s in English in that is is always pronounced in one and the same way. The structure of PNPs with genitives is, thus, very simple and uniform: attach $-s$ at the end of the possessor NP and put the whole expression in front of a possessee. This behaviour of the marker $-s$ justifies its analysis as a clitic (cf. Delsing 1993; Börjars 1994). In the $3^{\text {rd }}$ person pronouns hennes 'her', deras 'their' and dess 'its', however, $-s$ is clearly a bound morpheme since it combines with a special form of the pronominal stems.

Remarkably, in both English and in Continental Scandinavian the possessive clitic has replaced the earlier constructions with the morphological genitive case (for the history cf. Norde 1997).

Thus, the notion of PNP actually includes two different subtypes one with the invariable $-s$ - form and one with agreeing possessors. 
The property of agreement will not be considered in this paper, nor will the distinction of reflexive versus non-reflexive possessive pronouns.

\subsubsection{The meanings of PNPs}

PNPs cover a wide range of meaning relations. In some instances, the meaning relation is more or less determined by the semantics of the head nominal, as the case is with KIN relations ('Peter's brother') or BODY-PART vs. person/animal relations ('Peter's leg'), where the head noun is a typical relational noun. Non-relational nouns may enter into multiple relations with their possessors, the most prominent being that of LEGAL OWNERSHIP ('Peter's hat') and DISPOSAL ('Peter's office'); also mention should be made of TEMPORAL and LOCATIVE relations ('Monday's performance', 'Stockholm's banks'). However, one and the same noun phrase with preposed possessors can in principle be interpreted in various way; thus, Peter's bag, in addition to its "normal" interpretation 'a bag which belongs to Peter' may receive a number of other interpretations, even though some of these have a very little chance of occurring in real discourse - 'a bag which Peter is carrying for the moment but which not necessarily belongs to him', 'a bag which Peter has designed', 'a bag which Peter dreams of and therefore constantly talks of', etc.

The common semantic (or pragmatic) denominator in the majority of PNPs is the function of the possessors as anchors (Hawkins 1978, 1991; Fraurud 1990), or reference point entities (Langacker, e.g. 1991: 170, 1995; Taylor 1996: 17) for identification of the head's referents. In other words, in many instances we can identify the referent of a nominal via its relation to the referent of the genitive. Thus, knowing who Peter is we can identify Peter's bag, arm, brother: in Taylor's (ibid.) words, "in opting to use a possessive expression, the speaker is instructing the hearer on how best to identify the referent that he, the speaker, intends".

Clearly, however, not all entities are equally good in providing clues for identification of other entities. First of all, anchors them- 
selves have to be sufficiently salient in the context. Thus, accordingly, the best and most frequent possessors are humans. Also, most standard possessive NPs involve either definite (in the majority of cases $^{1}$ ) or indefinite specific possessors, with pronominal possessors representing the absolutely clearest and most frequent instances of definite human (or, occasionally, animate) possessors. More than that, indefinite inanimate possessors may be dispreferred in PNPs, which results in the alternation between PNPs and prepositional constructions. Thus, whereas kyrkans väggar 'the walls of the church' is perfectly all right, the PNP en kyrkas väggar 'the walls of a church' requires a very special context, with the more frequent alternative being väggarna på en kyrka 'the walls "on" a church'. There are also certain restrictions on what kinds of relations between what kinds of entities can be evoked in a standard possessive NP - both the category of the possessor and the possessee interact here in intricate ways. Thus, e.g. PNPs are dispreferred or even forbidden for reference to OBJECTS of deverbal nouns, where prepositional phrases have to be used. Cf. *Clintons val vs. valet av Clinton 'the election of Clinton' (cf. section 2.4, the discussion of the relation between PNPs and constructions with prepositional possessors).

\subsubsection{PNPs as definite NPs}

PNPs in Swedish have normally a definite interpretation, i.e., their referent is often unique within the pragmatic set of entities shared by the speaker and the listener (Hawkins 1978, 1991, also quoted in Haspelmath 1999b: 231; Teleman, Hellberg and Andersson 2000: 27-28). Thus, a sentence such as (1)
(1)
Var är Peter-s
where is Peter-GEN
'Where is Peter's shirt?'
skjorta?
shirt

normally presupposes that there is one particular shirt of interest in the current situation, which both the speaker and the listener can 
identify, even though Peter might have others as well. An appropriate reply to (1) would be Här är den 'Here it is', whereas by uttering Här är en 'Here is one' the speaker is not particularly cooperative. Unique reference, though usual is, however, not always necessary for using a PNP: sentence (2) does not presuppose that the speaker either has only one friend, or that (s)he and the listener can identify the one referred to by the PNP:

(2) Det här har jag hört av $\min$
DET here have I polare
'I've heard this from a friend of mine.'

In various morphosyntactic respects, PNPs are also treated as definite NPs. Before going into this issue, we have to say a few words about definiteness marking in Swedish NPs ${ }^{2}$.

Swedish has both indefinite and definite articles, which have different morphosyntactic status in that the indefinite article is a clitic introducing a NP (cf. en stol 'a:COM chair', ett bord 'a:N table'), whereas the definite article is a nominal suffix (stol-en 'the:COM chair', bord-et 'the: $\mathrm{N}$ table', stolar-na 'the:PL chairs') - more about its shape will be said in section 3.2. There is also a morphologically unbound preposed definite article (determinant) den/det/de used only under special conditions (see below). Adjectives distinguish between indefinite (strong) and definite (weak) forms, but the choice between those is always dependent on the presence of other (in)definiteness markers in the NP and can therefore be considered an agreement marker (Börjars 1994: 219), or secondary (in)definiteness indicator (cf. ett grön-t bord 'a:N green-N table' vs. detta grön- $a$ bord 'this: $\mathrm{N}$ green-DEF table').

It is possible to formulate the following GENERAL PRINCIPLE OF DEFINITENESS MARKING IN THE SWEDISH NP:

Definiteness in Swedish NPs is marked as early as possible (i.e., on the first word in a NP): either by means of preposed definite determiners, or, in the absence of such words, by means of the definite suffix on the first noun. 
The primary definiteness indicators in Swedish NPs show, thus, the following patterns:

1. Definiteness is marked by means of preposed definite determiners, such as demonstratives denna/detta/dessa 'this/these'; the words samma '(the) same', nästa '(the) next', foljande '(the) following', föregående '(the) preceding'; and possessors - cf. ex. (3) below.

2. In the absence of a definite preposed determiner, if a NP consists of a single noun or a noun followed by dependents (such as relative clauses, prepositional phrases, infinitives and subordinate clauses), definiteness is marked by means of the definite suffix on the head noun - cf. ex. (4) below.

3. With the preposed demonstratives den/det/de, often combined with the deictic adverb här/där 'here/there' for specifying deixis ('this'/'that'), head nouns have to attach the definite suffix. In this case, definiteness is marked twice, by elements which both can function independently as semantic determiners - cf. ex. (5a) below. This is termed DOUBLE DETERMINATION - a phenomenon specific to Swedish and Norwegian (cf. Börjars 1994 for a thorough analysis of this phenomenon). The same pattern is required whenever definite NPs involve adjectival modifiers or numerals. All the accompanying modifying adjectives appear in the definite form, which thus functions as an agreement marker. For some modifiers, the preposed determiner is optional, e.g. , for the ordinal numbers forsta '(the) first', andra '(the second)' etc., sista '(the) last', förra '(the) previous'. Cf. ex. (5b) below.

(3) Definiteness marked by means of preposed definite determiners
a. dettahus
'this: $N$ house'
b. samma hus
'(the) same house'
c. Peters hus
'Peter's house' 


\section{Björn Hammarberg and Maria Koptjevskaja-Tamm}

(4) Definiteness marked by means of definite suffixes on the head noun
a. Titta på hus-et!
Look at house-DEF.N
'Look at the house!'
b. Hämta klänning-en med rosor på.
fetch
'Fetch the dress with roses on it.'

(5) DOUBLE DETERMINATION - a NP combines two determiners (a preposed independent determiner and a definite suffix on the head noun)

a. det här hus-et

DET:N here house-DEF.N

'this house'

$\begin{array}{lll}\text { b. } & \text { det grön- } a & \text { bord-et } \\ & \text { DET:N green-DEF } & \text { table-DEF.N } \\ & \text { 'the green table' } & \end{array}$

Now, back to PNPs. PNPs are treated as definite NPs in various morphosyntactic respects:

- PNPs, as other definite NPs, are normally not allowed in existential constructions, cf. Det ligger en hatt på stol-en 'There is a hat lying on the chair' vs. *Det ligger Peter-s hatt på stol-en ?'There is Peter's hat lying on the chair'.

- PNPs are incompatible with indefinite articles and cannot be directly quantified by indefinite and negative quantifiers, such as någon 'some', ingen 'none', as well as by numerals.

(6)
a.
*en
Peters skjorta
a:COM/one:COM
Peter's shirt
b. några/inga/två
skjort-or
some:PL/none:PL/two
shirt-PL
'some/no/two shirts' 

c.
*några/*inga $/{ }^{*} t v a ̊$
skjort-or-na
some:PL/none:PL/two
shirt-PL-DEF.PL
d.
${ }^{*}$ några ${ }^{*}$ inga ${ }^{*}$ två
Peter-s
skjort-or
some:PL/none:PL/two
Peter-GEN
shirt-PL

- Adjectives following possessors and pertaining to the possessee appear in the definite form, cf. Peter-s grön-a bord 'Peter-GEN green-DEF table', i.e. 'Peter's green table' with the example in (5b).

- Finally, and most important for our purposes, preposed possessors (both pronominal and lexical) in Swedish NPs are incompatible with definite articles pertaining to the host nominal - either the definite suffix or the unbound preposed determiner, cf. Peter-s bord 'Peter's table', but not *Peter-s bord-et 'Peter-GEN table-DEF.N' or *det Peter-s bord 'DET:N Peter-GEN tableDEF.N'.

To summarise, PNPs are definite NPs, and, from the point of view of definiteness marking, preposed possessors in a NP align themselves with preposed definite determiners listed in 1 . above.

Whenever a possessee has to be explicitly indefinite, PNPs have to give place to other constructions - either to partitive constructions, (ex. (7a)), to compounds (ex. (7b)), or to prepositional constructions (ex. (7c)).
a. en/några/inga/tuå av Peter-s skjort-or one/some:PL/none:PL/two of Peter-GEN shirt-PL 'one/some/none/two of Peter' shirts'
b. en kung-a-son
COM/one:COM king-LINKER-son
'a king's son'
c. en
a:COM/one:COM
'a friend of mine'
friend to me
vän till mig 


\subsection{Compounds}

In noun-noun compounds the first part modifies the second. Compounds are also notorious for their multiple potential interpretations, or rather, for the vagueness of the semantic relation between their two parts, cf. änke-stuga 'widow-hut' (i.e., 'widow's hut', LEGAL OWNERSHIP or PREDESTINATION), hund-ben 'dog-bone' (i.e., 'dog's bone', BODY-PART), präst-dotter 'priest-daughter' (i.e., 'priest's daughter, KINSHIP), guld-ring 'gold-ring' (i.e., 'golden ring', MATERIAL), bröd-kniv 'bread-knife' (i.e., 'bread knife', PURPOSE) and höst-blommor 'autumn-flowers' (i.e., 'autumn flowers', TIME). (The hyphens are added here in order to show the components of the compound words.) Possible interpretations of a compound depend on the semantics of its parts and on the context.

As mentioned above, PNPs normally involve either definite possessors (in the overwhelming majority of cases) or indefinite specific ones. In compounds, on the contrary, the first part is normally nonreferential and its primary function consists in qualifying or classifying the second nominal, the whole compound functioning more or less as a classificational label. This has consequences for how the relation between the parts of a compound tends to be interpreted. Thus, classifications often imply a more or less stable situation, and an object previously classified as owned by a person of a certain type can all of a sudden come into possession by a completely different person. As a result, in compounds LEGAL OWNERSHIP or DISPOSAL par excellence often gives way to an interpretation of PREDESTINATION i.e., an object is supposed to be owned or used by a certain category, but does not have to. (8a) and (8b) illustrate the basic difference in use between PNPs and compounds:

a. Jag bor $i$ en students lägenhet.

'I live in a student's apartment.' (= an apartment belonging to a student)

b. Jag bor i en studentlägenhet.

'I live in a student apartment.' ( $=$ an apartment for students) 
Many compounds are lexicalised, but the process of compounding is on the whole very productive. Compounds are distinguished from word combinations and from simplex words by a special compounding prosody. For all morphological and syntactic purposes, nominal compounds behave like nouns, more particularly, like their last part. Thus, e.g., compounds show the usual nominal inflectional oppositions: en änke-stuga 'a:COM widow-hut', änke-stuga- $n$ 'widow-hut-DEF.COM', änke-stug-or 'widow-hut-PL', änke-stugor-na-s 'widow-hut-PL-DEF-GEN' etc.

The border between PNPs and compounds is, however, far from clear-cut.

1. Semantically, PNPs and compounds are sometimes quite close to each other. In certain cases noun-noun compounding and a genitive construction are both possible, sometimes with only a minimal semantic difference between the two. Thus, PNPs with a non-specific or generic possessor are very close to compounds, e.g. an elephant's trunk in the sentence An elephant's trunk can be two meters long might be translated into Swedish either as a PNP with a non-specific possessor, en elefants snabel, or as a compound en elefantsnabel.

Similarly, possible semantic differences are neutralised in the case of the PNP husets tak 'the roof of the house' vs. the compound hustaket 'the house roof' in the context There was a stork nest on the roof of the house. Since houses normally have one roof, one and the same entity is identified in both cases, either directly, by the compound, or by being related to the already identified entity.

Finally, some situations can be conceptualised in different ways, so that both PNPs and compounds, although semantically different, may be pragmatically equivalent. We will discuss this point in section 3.3.

2. Formally many Swedish noun-noun compounds are close to PNPs in that they are formed with a compound marker $-s-$, which, thus, looks like the genitive marker, e.g. värld-s-marknad-en 'worldLINKER-market-DEF.COM' (i.e., 'the world's market'). This marker has developed historically from a genitive inflection into a 
mere marker of the compound juncture - a situation familiar from quite a few other languages. In a few rare cases there are some other linkers, e.g. gat-u-korsning-en 'street-LINKER-crossing-DEF.COM' (i.e., 'the street crossing'). More often, the two parts of a compound appear as juxtaposed to each other, e.g. pojk-skjorta 'boy-shirt' (i.e., 'a boy's shirt').

3. Finally, in Modern Swedish there is an ever growing tendency to write the parts of compound words as separate words - a usage condemned by Swedish normative linguists, but attested in writing even with those (usually young) Swedes who otherwise follow the standard spelling rules (for some discussion cf. Mobärg 1998).

To conclude, even though the standard possessive NPs and compounds in prototypical cases are quite different entities, they sometimes converge on such important parameters as semantics, morphosyntactic makeup and spelling.

\subsection{Constructions with postposed prepositional modifiers}

In Swedish, as in related Germanic languages, constructions with genitives or possessive pronouns can alternate with prepositional constructions to express various types of possessive relations. Curiously, the relations of LEGAL POSSESSION (Jennys bok 'Jenny's book'; min bok 'my book') and DISPOSAL (sekreterarens rum 'the secretary's office') cannot be expressed by a prepositional construction in Swedish, but have to be rendered with a genitive or a possessive pronoun.

Some languages have a common preposition expressing a possessive. Thus, e.g., English of, German von, Spanish de, Hebrew šel, and Bulgarian $n a$ are used as "general possessive preposition". The Scandinavian languages, however, use different spatial prepositions in many types of possessor-possessee relations where related languages will use a standard possessive preposition. The rationale for this is of course the relatedness of spatial inclusion and possession. 
This merging of spatial and possessive conceptualisations results in what we may call locative-possessive constructions, i.e. constructions with various types of spatial prepositions which correspond in meaning to constructions with genitives or possessive pronouns. The two constructions can alternate under favourable conditions, even though the prepositional constructions can sometimes express additional meaning nuances as compared to the corresponding PNPs (e.g., the difference between ingredienserna i/till soppan 'the ingredients "in"/"to" the soup' in the list below). This applies in Swedish particularly in certain types of possessor-possessee relations, such as

LOCATION WITHIN DOMAIN:

huvudstaden i Ghana

invånarna i Stockholm

PART-WHOLE:

benet på stolen

ingredienserna i soppan

BODY-PART:

kinden på Lisa

i magen på fågeln

SUBSET:

några bland barnen

POSSESSED QUALITY:

färgen på blomman

namnet på gatan

kompetensen hos personalen

fördelen med förslaget

REPRESENTATION:

teori om film

historia över måleriet

CONNECTION:

locket till burken

ingredienserna till soppan

INTERPERSONAL RELATIONS:

en granne till oss 'the capital "in" Ghana'

'the inhabitants "in" Stockholm'

'the leg "on" the chair'

'the ingredients "in" the soup'

'the cheek "on" Lisa'

'in the stomach "on" the bird"

'some "among" the children'

'the colour "on" the flower'

"the name "on" the street

"the competence "at/with" the staff

'the advantage "with" the proposition'

'theory "about" film'

'history "over" painting'

'the lid "to" the jar'

'the ingredients "to" the soup'

'a neighbour "to" us' 
KINSHIP:

pappan till bröderna

CAUSE:

orsaken till olyckan 'the dad "to" the brothers'

'the cause "to" the accident'

In cases like the ones cited, the underlying spatial sense is that of 'location at/on/in/with etc' or 'direction to'. Here the preposition $a v$ 'of' is ruled out. But where the underlying spatial sense is that of 'direction from', source prepositions such as av 'of', från 'from', efter 'after' are used:

TRACE:

spår av/efter tjuvarna

resterna av/från/efter måltiden

RESULT/EFFECT:

konsekvenserna av misstaget

ORIGINATOR:

symfonier av Mozart 'traces of the thieves'

'the remains of the meal'

'the consequences of the mistake'

'symphonies by Mozart'

In some cases of PART-WHOLE or SUBSET relations it is possible to use either $a v$ or a locative-possessive variant, as e.g. en avdelning av/i bolaget 'a division "of/in" the company', $i$ början av/på april 'in the beginning "of/on" April', några av/bland dem som var med 'some "of/among" those who were present', thus giving more prominence either to the partiality or to the location. In Standard Swedish there is a (somewhat fuzzy) border zone in this area. $A v$ tends to be preferred when the head noun (the possessee) presupposes a relation of partiality and, to a certain degree, quantification. While en vägg på huset 'a wall of the house' is preferred to en vägg av huset, en del av huset 'a part of the house' could not be rendered as *en del på huset - an important difference between 'a wall' and 'a part' is that the first word denotes an entity which in principle can be recognised without the whole (the house), while the latter can only be understood in relation to the whole. And in general, PARTITIVE constructions consisting of a nominal measure word quantifying definite entities, involve $a v$, e.g. en kopp av det goda kaffet 'a cup of the good 
coffee'. By contrast, NPs with nominal measure words quantifying indefinite entities simply involve juxtaposition of the two, e.g. en kopp kaffe 'a cup (of) coffee'.

A special case of variation occurs with pictures, where på competes with $a v$ in the DEPICTING relation, whereas $a v$ prevails in the ORIGINATOR relation; for details of this competitive situation cf. Lyly's (1996) discussion of examples like en bild på/av Picasso 'a picture of P.' as compared to en bild av Picasso 'a picture by P.'.

$A v$ is also used to mark OBJECTS of deverbal nouns, as in Alexanders erövring av Egypten 'Alexander's conquest of Egypt', and not *Alexanders Egyptens erövring or *Egyptens erövring av Alexander.

Thus, the choice of a preposition introducing a postposed attribute is most often intimately connected with the semantics of the head noun. This is obvious for typically relational nouns, such as bodyparts nouns and nouns referring to other parts, kin terms and nouns referring to other interpersonal relations, or words like consequence or result - not only do these words invoke a special relation to another entity, but cannot simply be understood without this entity. Thus, a person cannot be a neighbour or a son without being someone's neighbour or son. It seems, however, that many more nouns are relational in a weak sense, in that their meaning itself presupposes or invokes specific relations. Thus, although a book can perfectly well be conceptualised without any reference to other entities and there are no problems at all with sentences like Here's a book, as opposed to *Here's a wife, books are strongly associated with their authors and with their content. In other words, the semantic structure of the word book readily invokes relations of ORIGINATOR (en bok av Strindberg 'a book by Strindberg') and of REPRESENTATION (en bok om Japan 'a book about Japan') ${ }^{3}$. In this perspective, the absence of a preposition for coding the relations of LEGAL POSSESSION and DISPOSAL might perhaps be interpreted as a symptom of the essential difference between these and all the other relations listed above: the former are much more general and much more loosely connected to the semantics of particular nouns than the latter. After all, all arte- 
facts and certainly many more concrete entities are potentially possessible and/or at someone's disposal.

A prepositional construction is particularly useful when the possessee is indefinite. Thus, for example, while husets väggar and väggarna pa huset 'the walls of the house' are both possible, en vägg på huset 'a wall of the house' cannot be rendered with a genitive. Also, as mentioned in section 2.2.1, whereas PNPs are frequent with animate and definite possessors, inanimate indefinite possessors very often call for other constructions, primarily prepositional constructions, such as väggarna på ett hus 'the walls of a house'. In many contexts, a prepositional construction is perceived stylistically as less formal than a genitive.

However, when a possessee in the relation of LEGAL POSSESSION is indefinite, the corresponding expression will be a partitive construction of the type illustrated in ex. (7a) in section 2.2.2.

\subsection{The Swedish system of adnominal possession: summarising}

Table 1 summarises the various formal and semantic properties of the three constructions described in sections $2.1-2.4$.

As mentioned in section 1, linguistic possession is hard or even impossible to define. However, most people would agree that the core of this category is made up of cases where there is an exclusive asymmetric long-term relation between two entities - for each possessee there is only one possessor, who has the right to make use of the possessee - and the possessor is an individuated human being (cf. Taylor 1996: 340). In accordance with this, PNPs in Swedish constitute the best expression format for adnominal possession since it covers all the more prototypical cases of this category. Both other construction types provide worse matches here: in compounds, the possessor is not individuated, and constructions with postposed prepositional modifiers cannot express LEGAL POSSESSION and DISPOSAL. 
Table 1. Summary of the formal and semantic properties of the major adnominal possessive constructions in Swedish. $\mathrm{D}=$ Possessor; $\mathrm{H}=$ Possessee.

\begin{tabular}{|c|c|c|c|}
\hline Properties & PNPs & Compounds & $\begin{array}{l}\text { NPs with preposi- } \\
\text { tional modifiers }\end{array}$ \\
\hline $\begin{array}{l}\text { Morphosyntactic } \\
\text { status }\end{array}$ & Definite NP & Noun & $\mathrm{NP}$ \\
\hline $\begin{array}{l}\text { Order of Possessor } \\
\text { (D) and Possessee } \\
\text { (H) }\end{array}$ & D-H & D-H & H-D \\
\hline $\begin{array}{l}\text { Reduction of inflec- } \\
\text { tion and/ or combi- } \\
\text { nability }\end{array}$ & $\begin{array}{l}\text { For } \mathrm{H} \text { : no articles are } \\
\text { permitted. Normally } \\
\text { only definite inter- } \\
\text { pretation for } \mathrm{H} \text {. }\end{array}$ & $\begin{array}{l}\text { For D: no inflec- } \\
\text { tional categories. } \\
\text { Normally only non- } \\
\text { specific interpreta- } \\
\text { tion for D. }\end{array}$ & {[} \\
\hline $\begin{array}{l}\text { Markers of relation } \\
\text { between } \mathrm{H} \text { and } \mathrm{D}\end{array}$ & $\begin{array}{l}\text { The clitic -s in the } \\
\text { majority of cases; } \\
\text { Agreeing possessive } \\
\text { pronouns for } 1 \text { and } 2 \\
\text { person, and reflex- } \\
\text { ives. }\end{array}$ & $\begin{array}{l}\text { No marker, or the } \\
\text { linking elements - } \\
\text {-s- and, sporadically, } \\
\text { a few others. The } \\
\text { choice determined by } \\
\text { several factors, often } \\
\text { in an unpredictable } \\
\text { fashion. }\end{array}$ & $\begin{array}{l}\text { Different preposi- } \\
\text { tions for different } \\
\text { relations. The choice } \\
\text { often determined by } \\
\text { semantics of the } D \text { in } \\
\text { a fairly complicated } \\
\text { fashion. }\end{array}$ \\
\hline
\end{tabular}

Disfavouring factors Indefiniteness of $\mathrm{H}$. Specificity of D. Primarily semantic: Other semantic facsome relations, such tors (types of relations) to a certain degree. as LEGAL POSSESSION and DISPOSAL.

Other alternatives under disfavouring conditions.
For LEGAL POSSESSION and DISPOSAL: partitive constructions. For other relations: constructions with prepositional modifiers. With nonspecific D: compounds. 
With regard to the simplicity of their form, PNPs, and particularly those with $s$-genitives, are also clearly superior to the other two constructions. The choice between the two formal subtypes (the one with a possessive pronoun that shows agreement and an $s$-genitive) is completely transparent, and $s$-genitives are formed in an absolutely uniform way. In compounds, the choice of the technique for combining the two parts (no marker, the $-s$-linker or other linkers) is often difficult to determine, and the same concerns the choice of the preposition for postposed modifiers to nouns.

In short, PNPs, in particular those with s-genitives, are an unmarked, or default construction for adnominal possession in Swedish.

\subsection{The typological profile of the Swedish system of adnominal pos-} session

In what follows we will provide a general typological background for the two aspects of the Swedish system of adnominal possession which in one way or another are typologically interesting and can present problems in L2-acquisition:

- the definiteness of PNPs, and

- the existence of several adnominal possessive constructions

\subsubsection{Possessor-article complementarity and definiteness of PNPs}

Swedish, or rather Mainland Scandinavian, is of course not unique in showing possessor-article complementarity - such languages are attested in several families and areas, e.g English, Welsh and Irish, Romani, Vai, Amharic, Hebrew and Maltese. They are opposed to others, such as Portuguese and Italian, in which possessors co-occur with (and, normally, even require the presence of) articles, cf. Ital. un mio vestito 'one of my dresses' vs. il mio vestito 'my dress', as well as un/il bel vestito di Anna 'a beautiful dress of Anna's/Anna's beau- 
tiful dress'. Finally, in still other languages, such as most of the Slavic languages or Chinese, the question of possessor-article complementarity simply does not arise due to the lack of grammaticalised articles.

There are also concomitant cross-linguistic differences in the interpretation of possessive NPs: while PNPs in Swedish are normally definite, their counterparts in Italian, Russian and Chinese may be both definite and indefinite, depending on the article (in the Italian case) and/or on the context.

A fairly well-spread structural account suggests that articlepossessor incompatibility follows from a requirement for a unique determiner position in a NP (a claim which itself can be debated). In languages of the Swedish type, possessors occupy the determiner slot in a possessive NP. In languages like Italian, possessors have a different structural status, comparable to those of modifying adjectives, cf. examples above with un bel vestito 'a beautiful dress' and il bel vestito (Lyons 1986: 138; Giorgi and Longobardi 1991). The fact that possessors and definite articles in Swedish are structurally and positionally different - possessors introduce the NP, while articles are suffixes on the head noun - is a complication for this analysis.

Haspelmath (1999b) and Koptjevskaja-Tamm (forthc. b) suggest instead that article-possessor complementarity in certain languages has a functional rationale stemming from the frequent function of the possessors as anchors or reference point entities for identifying other entities. Thus, Haspelmath (1999b: 227) states that

such patterns of article-possessor complementarity are ECONOMICALLY MOTIVATED (in the sense of Haiman 1985): the definite article can be omitted because possessed NPs have a very high chance of being definite, for semantic and pragmatic reasons ... By conventionalising an articleless possessive construction languages obtain a syntactic pattern that allows for more economical (i.e., shorter) utterances.

Languages like Italian, on the other hand, show preference for EXPLICITNESS at the cost of economy. Haspelmath argues also that the functional account has a better explanatory value, in particular for 
those languages where the article and the possessor appear in different positions with Swedish as an example par excellence.

\subsubsection{Splits in the system of adnominal possession}

Co-occurrence of several different possessive constructions in one and the same language is a fairly frequent phenomenon; there are various recurring types of split possession systems in the world's languages. The alternating possessive constructions are thus opposed to each other according to various parameters. In the case of Swedish, as in many other languages, these parameters include properties of possessors, properties of possessees and the type of relation between a possessor and a possessee.

1. PNPs vs compounding: anchoring vs non-anchoring relations. The choice between PNPs and compounds is mainly determined by specificity vs. non-specificity of possessors: only the former can normally function as anchors in anchoring relations. Quite a few languages have different constructions for expressing anchoring and non-anchoring relations, even though the details may differ. Thus, non-anchoring relations can be expressed by compounds, by constructions with denominal adjectives ("relational adjectives") or by structures which share certain, but not all morphosyntactic properties with standard possessive NPs (e.g., English, in which examples like $a$ women's magazine have been analysed differently by different linguists, as involving descriptive or classifying genitives, or as possessive compounds). A common formal denominator across these strategies is a reduction of typical nominal inflectional and combinatorial properties by a non-specific modifier.

It is, however, even more usual to have one and the same construction for both anchoring and non-anchoring relations.

2. PNPs vs locative-possessive prepositional constructions. The choice between PNPs and locative-possessive prepositional constructions is mainly determined by the (in)definiteness of possessees, 
by the type of relation between the possessee and the possessor, as well as by stylistic factors (cf. the end of section 2.4). All these factors are known to be instrumental in split possession systems across languages, but the details differ considerably, and rarely do the factors interact in such an intricate way as they do in Swedish. PNPs are by far more frequent than any one of the prepositional constructions and even all of them together.

3. Choice of preposition in locative-possessive constructions. Finally, the choice among the different prepositions in locative-possessive prepositional constructions is determined by the semantics of a possessee and its relation to a possessor. As we saw in section 2.4, the most prominent prepositions in the locative-possessive system are $p \stackrel{0}{a}$ 'on', till 'to' and $a v$ 'of/from'. Spatial markers with more or less comparable semantics (AT/ON, TO and FROM) are generally known to give rise to possessive markers across languages. One reason for this is the abstractedness of linguistic possession as a cognitive domain. Thus, e.g., how do we actually know that a hat is Peter's or that Mary is John's wife? Figuring this out or understanding what this would mean would demand quite complicated perceptual and cognitive strategies and a huge cultural background. A basic and generally applied cognitive strategy for dealing with relatively abstract, less easily accessible or understandable domains is by understanding and describing them in terms of more concrete domains (cf., e.g., Lakoff and Johnson 1980; Heine 1997: 45). Spatial experiences are fairly easily accessible - under normal circumstances no great efforts are required for seeing whether a hat is on Peter's head, or is in his hand or is not in his vicinity at all. Moreover, an experience (in particular, if it is repeated) of seeing a hat on Peter's head gives rise to a natural inference that it is his. Likewise seeing Mary and John together, in the spatial proximity to each other in various places can, under certain circumstances, be a ground for suspecting that they are a couple. Thus, spatial experiences can be used for understanding possession and spatial expressions, and therefore provide an important grammaticalisation source for possessive expressions (Heine 1997: 45186; Koptjevskaja-Tamm forthc. a). 
Grammaticalisation leads to expansion and generalisation of one spatial marker to the whole cognitive domain of possession and the gradual loss of the others. There are signs in the locative-possessive prepositional system that witness to such ongoing grammaticalisation processes. Thus, e.g., as mentioned above, some of the prepositions are the clear "leaders" in the sense that they take care of the main bulk of the relations expressed in the system, with the result that there is a certain degree of apparent arbitrariness in the choice of prepositions in Swedish. Historical changes in the distribution of the prepositions are described for the older periods of Swedish by Norde (1997) and for the latest 300 years by Pitkänen (1979). Pitkänen's data point to the conclusion that the least marked and the more expanding preposition during that period has been $p a ̊$ 'on'. However, both till 'to' and $a v$ 'from' show a high degree of grammaticalisation; this is particularly obvious in the case of $a v$ which in Modern Swedish is used very restrictedly for referring to spatial relations, compared to its more abstract uses. The present Swedish system might perhaps be seen as transitional from the stage when more prepositions were actively involved and the choice between them was sufficiently transparent, to a stage when one spatial preposition is generalised to a large portion of the possession domain. Among the Scandinavian languages the latter case is found in Norwegian with its preposition $t i l$ 'to' as the general possessive marker and some of the Norwegian and Northern Swedish dialects (curiously, the general possessive preposition in these varieties comes either from TO or from FROM). In standard Swedish and Danish, and also Faroese (cf. Stolz with Gorsemann forthc.) the grammaticalisation processes have not yet been carried through. Transitional systems are generally characterised by a high degree of complexity, and this is also true of the Swedish locative-possessive system. 


\section{Problems facing learners of Swedish as L2}

\subsection{The data source}

In order to obtain evidence for how Swedish possessive constructions are handled by young adult L2 learners, we have used the $A S U$ Corpus, a text database which has been compiled in the nineties at the Department of Linguistics, Stockholm University. This is a body of Swedish recorded conversational speech and written essays collected from foreign and native university students in Stockholm. For the present purpose, the written learner part of the corpus has been used. Cf. Hammarberg (1999) for a full account of the design and contents of the ASU Corpus.

The learner part of the corpus is longitudinally designed, tracing the developing interlanguage from the beginner stage when the subjects had just arrived in Sweden and began their university language preparatory course, to a stage where they were participating in university studies in Swedish. Ten subjects, 3 women and 7 men aged 19-28, were followed, representing various Lls. They will be referred to below with a letter-and-digit identification: German and English, represented by a bilingual L1 speaker (subject E2), Portuguese (Q1, Q2), Spanish (S1), Greek (G2, G3), Polish (P1) and Chinese $(\mathrm{C} 1, \mathrm{C} 2, \mathrm{C} 4)$. (Concise typological information on adnominal possession in these languages is given in the Appendix.) The subjects each produced two short essays on each of 11 occasions, which yielded a total of 220 texts, or 50000 word tokens. The texts comprise narratives, descriptions and discussions on given general and current topics.

The subjects can be broadly characterised as "semi-formal learners", since they lived in the Stockholm area at the time and received their Swedish language input partly from the course and partly from the outside environment. All corpus material was collected in separate sessions outside class and was not evaluated in the course. They can be categorised as "qualified learners" in the sense that they all had secondary education, previous experience with foreign languages, and strong instrumental motivation to learn the language of the host country in order to proceed with the studies in their fields. 
All were acquainted with English and most of them with one or two other L2s prior to Swedish. Relatively speaking, they were "fast learners" since they proceeded from the beginner stage through or close to the Swedish proficiency level required for university studies in Sweden within one to two years. Their overall L2 development did not show a noticeable plateau, but progressed continuously. They certainly did not reach perfection in L2 during the period of observation; rather, the corpus spans stages when complex grammar and discourse structure was gradually taking shape in their free production.

Generally speaking, the interlanguage of these learners differs considerably from the type that has been described in major European L2 research projects, such as the Heidelberg Project (Klein and Dittmar 1979), ZISA (Clahsen, Meisel and Pienemann 1983) and the "ESF Project" (Perdue 1993). It is clearly more target-oriented. Thus the present corpus does not display an extended period dominated by a "basic variety" (cf. Klein and Perdue 1997), but the learners are inclined from early stages to develop a grammaticalised interlanguage (here in the sense of acquisitional grammaticalisation). Although this can be observed also in the learners' oral production (as evidenced in Hammarberg 1996, 2000), it is particularly obvious in the written part of the corpus which we have chosen to investigate here.

The 11 sessions of data collection were distributed with five sessions (Time 1-5) from September to December 1990, four sessions (Time 6-9) from January to May 1991, one (Time 10) in March 1992, and one (Time 11) in April 1993.

We have excerpted and analysed the instances of adnominal possessive constructions occurring in the written learner corpus and will concentrate here on the various types of target-deviant solutions that occur, and the acquisitional problems that they evidence.

Productive use of possessive constructions emerges already in the early sessions with some of the subjects, but the bulk of instances appear in the second semester and thereafter (Time 6-11). No clear time sequence of developmental solutions for possessive constructions can be observed in the data we have inspected (which does not rule out the possibility that other comparable learner language data might be more conclusive in this respect). Yet it is clear enough that 
there are some tendencies for the learners to use certain specific patterns of target-deviant solutions or to favour particular constructions. We will discuss and exemplify such cases in the following sections.

\subsection{PNPs and definiteness}

In sections 2.2.2 and 2.6.1, we described the the following typologically interesting properties of Swedish PNPs:

- PNPs are inherently definite; and

- possessors in PNPs function as preposed definiteness markers in being incompatible with definite articles and requiring definite forms for the following adjectives.

As should be clear from the discussion, the two properties are actually two sides of one and the same phenomenon, particularly seen "from the inside" of the Swedish nominal system with its highly grammaticalised definiteness category. Our corpus shows that learners can have problems with both of them (in what follows, for considerations of space, we will not consider the form of adjectives in PNPs).

In the example (9) the PNP is treated as an indefinite NP in two respects: by occurring in the existential context and by containing an indefinite quantifier många 'many' (cf. the end of section 2.2 and ex. (6)). Here, as in subsequent learner's examples, we first give the learner's version with an English word-by-word gloss, then a reconstructed Swedish target version followed by an English translation of the target version. It should also be noted that, to save space, we omit the glossing of gender in learner utterances, since the choice of gender has no bearing on the present topic. A source reference is given by stating the subject and the session of data collection; thus " $\mathrm{Cl} 1-3$ " refers to subject $\mathrm{C} 1$, session 3 .

$$
\begin{array}{lllll}
\text { Det } & \text { fanns } & \text { många Mings } & \text { vänner } & \text { i hans } \\
\text { there } & \text { were } & \text { many } \text { Ming-GEN } & \text { friend-PL } & \text { in his }
\end{array}
$$




\section{Björn Hammarberg and Maria Koptjevskaja-Tamm}

rummet.

room-DEF.SG

'Det fanns många vänner till Ming i hans rum.'

'There were many friends of Ming's in his room.' (C1-3)

Interestingly, a sentence later the same learner tries to use a periphrastic construction of the partitive type for the same purpose.

Det fanns olika personer av Mings vänner
there were various persons of Ming-GEN friend-PL
som komde från Kina förstårs
who came from China of course
'Det fanns olika vänner till Ming, som kom från Kina
förstås.'
'There were various friends of Ming's, who came from China
of course.' (C1-3)

There are several instances in which PNPs contain indefinite articles, showing thus other signs of being treated as indefinite NPs:

$$
\begin{aligned}
& \text { en stor landets } \quad \text { stad } \\
& \text { IND.ART big country-DEF.SG-GEN town } \\
& \text { 'en stor stad på landet', 'en stor landsortsstad' } \\
& \text { 'a big town in the country', 'a big countryside town' (G2-8) }
\end{aligned}
$$

Much more frequent in our corpus are examples in which the head noun in a PNP erroneously attaches a definite suffix, cf. (12):
a. hennes huvudet her head-DEF.SG
'hennes huvud'
'her head' (P6-3)
b. ... men jag tycker om läsar tidningarnas familjesidan
‘... men jag tycker om att läsa tidningarnas familjesida.'
'... but I like reading the papers' family page.' (C4-7) 
In what follows we suggest two different interpretations for such errors which we will refer to as DEF-in-PNP1 and DEF-in-PNP2. To show our grounds for these interpretations we have chosen two texts by one and the same learner, $\mathrm{C} 4$. Since her native language, Chinese, lacks a grammatical category of definiteness in nouns, in acquiring Swedish she is confronted with the task of understanding both the semantics of this category in Swedish and its complicated system of (in)definiteness marking.

The learner $\mathrm{C} 4$ during session 4 shows that she is coming to grips with the simplest definiteness alternations in Swedish. This is shown in Table 2. The learner is clearly following the rule that new referents in a discourse are often introduced in an indefinite form, but starting from the second mention are treated as definite NPs. This is seen in the introduction of and the subsequent reference to the main protagonists in the story - a ticket seller and three men, where definite suffixes are used in the second mention, combined with the preposed determiner in the case of numeral expressions. The same pattern, however, is applied to the word handväska 'hand bag', which is introduced with an indefinite article, but on the second mention is used as the head of a PNP with the preposed possessor hennes 'her' and the definite suffix. In learning the Swedish definiteness marking system, learners of Swedish have to acquire both the different patterns for expressing definiteness (by a preposed definite determiner, by a definite suffix on the head noun and by combination of the two), and also keep in memory their distribution, which is far from obvious. Thus, why should the demonstrative denna require the absence of the definite suffix on the head noun, whereas the demonstratives den and den här require its presence? Similarly, why should the same difference be triggered by the words samma '(the) same', nästa '(the) next', följande '(the) following', föregående '(the) preceding', as opposed to andra '(the second)' and förra '(the) previous'? In a corpus of spoken data from 60 learners of Swedish, Axelsson (1994) observes that single nouns with definite suffixes are the second most frequent type of definite lexical NPs (following proper names), even though the learners make mistakes with the pattern for a longer time than with PNPs. In language instruction, the definiteness category it- 
self is also normally introduced and exemplified by the simplest definiteness alternation of the type en kassörska $\rightarrow$ kassörskan.

Table 2. Referent chaining in C4-4.

\begin{tabular}{|c|c|c|c|c|}
\hline Referent & First mention & $\begin{array}{l}\text { Indefiniteness } \\
\text { marking }\end{array}$ & Second mention & $\begin{array}{l}\text { Definiteness } \\
\text { marking }\end{array}$ \\
\hline $\begin{array}{l}\text { Ticket } \\
\text { seller }\end{array}$ & en kassörska & $\begin{array}{l}\text { Indef. article } \\
\text { with nouns in } \\
\text { SG }\end{array}$ & kassörskan & $\begin{array}{l}\text { Def. suffix on } \\
\text { single nouns } \\
\text { (pattern } 2 \text { in sec- } \\
\text { tion } 2.2 .2 \text {.) }\end{array}$ \\
\hline $\begin{array}{l}\text { Three } \\
\text { men }\end{array}$ & Tre män & $\begin{array}{l}\text { No indef. art. } \\
\text { with nouns in } \\
\text { PL }\end{array}$ & $\begin{array}{l}\text { de tre mänen } \\
\text { (for 'de tre } \\
\text { männen') }\end{array}$ & $\begin{array}{l}\text { Preposed deter- } \\
\text { miner and def. } \\
\text { suffix on the head } \\
\text { noun 'overdeter- } \\
\text { mination', pattern } \\
3 \text { in section } 2.2 .2 \text {.) }\end{array}$ \\
\hline $\begin{array}{l}\text { A hand } \\
\text { bag }\end{array}$ & En handväska & $\begin{array}{l}\text { Indef. article } \\
\text { with nouns in } \\
\text { SG }\end{array}$ & $\begin{array}{l}\text { Hennes } \\
\text { handväskan }\end{array}$ & $\begin{array}{l}\text { Error: preposed } \\
\text { possessors are in- } \\
\text { compatible with } \\
\text { def. suffix on the } \\
\text { head noun (pat- } \\
\text { tern } 1 \text { in section } \\
2.2 .2 \text {.) }\end{array}$ \\
\hline
\end{tabular}

Thus, it seems reasonable to us that the sheer frequency of the patterns involving definite articles combined with the attention it gets in language instruction can lead to one possible reason for the errors of the type "head noun + DEF in PNPs":

DEF-in-PNP1: The most frequent type of definite marking in NPs involves single nouns marked with the definite suffix. In L2 acquisition this pattern is overgeneralised to other definite NPs, including PNPs.

DEF-in-PNP1 can be seen as an example of what Andersen (1984: 79) has called the "One-to-One Principle" in L2 acquisition, "An in- 
terlanguage system should be constructed in such a way that an intended underlying meaning is expressed with one clear invariant surface form (or construction)". The corpus shows similar generalisations of the simplest definiteness patterns for other cases. Thus, e.g., the learner E2 on session 5 writes samma tiden instead of samma tid 'the same time' (since on an earlier occasion he used the word form tid it is reasonable to suggest that tiden is used here as the definite and not an unalysed basic form). And in general, the definiteness marking of NPs with the word samma 'same' causes problems for several learners.

The data above point to the conclusion that the learner $\mathrm{C} 4$ erroneously generalises the simple definiteness marking pattern by means of definite suffixes to PNPs. However, sometimes the same learner makes errors of the same type, but, most probably, motivated by a different reason - the definite form of a word is wrongly analysed as its basic form. Thus, during session 7 , the learners were asked to write a text with the title "Familjesidan $i$ en daglig tidning" - "The family page in a daily newspaper'. The word familjesidan 'the family page' was thus introduced in the definite form already in the title of the task itself. In the essay produced by $\mathrm{C} 4$, this word occurs only in this form, all in all five times. In three of these contexts the definite suffix is used wrongly, because either the context requires an indefinite form (cf. ex. 13) or the noun functions as the head of a PNP (ex. 12b):

(13) Det finns inte familjesidan i kinesiska tidningarna.

'Det finns ingen familjesida i kinesiska tidningar.'

'There is no family page in Chinese newspapers.' (C4-7)

Similar use of familjesidan and other comparable nouns as unanalysed basic forms is also found with other learners in the corpus.

On the basis of such cases we suggest the second possible reason for errors of the type "head noun + DEF in PNPs":

DEF-in-PNP2: The definite form of a noun is sometimes perceived as its basic form. 
The main reason for this are the various morphosyntactic properties of the Swedish nominal suffixes which may lead to considerable difficulties in finding out the basic form for a certain noun. And in fact, the corpus contains a number of nouns with definite suffixes used in typical contexts for basic forms - e.g., en fabriken 'a factoryDEF.COM' (C4-7), en sidan 'a page-DEF.COM' (C1-11), en stor skoggen 'a big forest-DEF.COM' (E2-2). Earlier studies on L2 acquisition of Swedish (cf. Axelsson 1994; Wijk-Andersson 1993) show that the relative degree of correctness in the use of definite suffixes in Swedish is often higher at the earliest stage of L2 acquisition than during some of the subsequent stages. The explanation suggested is in the line with ours - a number of very frequent nouns are acquired in the definite form, while the productive and correct use of the definite suffix starts later.

Axelsson (1994: 49) also notes several cases of nouns taking definite suffixes in the presence of possessors and some other preposed determiners which in Standard Swedish are not compatible with this pattern. She suggests basically the same two explanations as we have done in this section.

The two explanations do not, of course, exclude each other, and in many cases it is difficult to find sufficient evidence for which of the two is at work. Both, however, provide a good account for why errors of the type "head noun + DEF in PNPs" occur at the early stages in the acquisition of the definiteness category. However, while the DEF-in-PNP1 is a phenomenon intrinsically connected to the properties of PNPs in Swedish, the DEF-in-PNP2 stems from the Swedish nominal morphology in general.

\subsection{Genitive constructions and compounds}

All the learners spontaneously form both PNPs and noun-noun compounds. Often, however, a PNP, or more precisely, a nominal genitive construction is used in contexts where a compound would be more appropriate. The general tendency is to overuse the genitive at the expense of the compound, not the reverse. Typical instances of 
this are cases where the first noun is not intended to be referential and should hence not normally be constructed as a possessor in a PNP. Thus, sentence (8a) in section 2.3 above is actually cited from a learner's text (G2-4), but known facts reveal that the intended meaning is that of $(8 b)$.

The issue is complicated by the fact that the formal distinction between a genitive construction and a compound is often not very clearly expressed in the learners' production.

Several factors combine to yield this effect. First, as we noted in section 2.3 above, many Swedish noun-noun compounds are formed with a linker, or compound marker $-s-$, which is similar to the genitive clitic. Learners use - and overuse - the linking $-s$ - productively in many compound formations, as e.g. in oljaspris for 'oljepris' 'oil price' (C2-6).

Secondly, learners occasionally also form compounds with the first noun inflected for plural or definiteness as well, e.g. tidningarsläsning 'newspaper-PL-s-reading' for 'tidningsläsning' (C1-6), högskolansprov 'university-DEF.SG-s-test' for 'högskoleprov' (C2-10). This results in target-deviant word structures. But considering the fact that learners do produce such formations where the first noun of the compound is obviously inflected, it may well be the case that they similarly perceive the $-s$ - in compounds as a true genitive marker.

Thirdly, the learners often tend to write compounds as separate words. Although this can also be observed with many young Swedes today, the phenomenon is even more frequent with the learners.

Separated compounds in combination with the two other factors just mentioned results in a variety of structures in the learners' production. Focusing on the form of the first noun, we may distinguish the following structure types:

1. The two nouns are merely juxtaposed as two graphic words, e.g. tunnelbana station for 'tunnelbanestation' 'tube station' (Q1-8), introduktion kurs for 'introduktionskurs' 'introduction (introductory) course' (S1-9). Examples of this type are quite common in our data, and are attested with all the ten learners. The instances occurring in 
the corpus generally represent cases where compounding is an appropriate strategy.

2. The first noun is marked for plural or definiteness: bilar fabriker 'car-PL factory-PL' for 'bilfabriker', 'car factories' (S1-4), samhället politik 'society-DEF.SG politics' for 'samhällets politik' or samhällspolitiken' 'the politics of society' (C1-8), framtiden melodi 'futureDEF.SG melody' for 'framtidens melodi' 'the melody of the future' (G3-8). Such cases are target-deviant. They are rare in the corpus, only stray examples occur.

3. The first noun is marked with $-s$ and may also carry a plural and/or definiteness marking. This type regularly produces target-like, appropriately used genitive constructions, either with an indefinite possessor, as in människors liv 'people's lives' (E2-7), andra länders konkurrens 'other countries' competition' (G3-9), or with a definite possessor such as mannens skor 'the man's shoes' (S1-5), nästa generations ungdomar 'the next generation's young people' (E2-10). But there also occur genitive constructions which are inappropriately used, i.e. cases which by formal criteria have the structure of a PNP but contain a non-specific first noun, e.g. $i$ sin fisks tallrik for 'på sin fisktallrik' 'on his plate of fish (fish plate)' (G2-2), en vanlig tidnings sida for 'en vanlig tidningssida' 'an ordinary page from a newspaper (newspaper page)' (Q1-7). An additional determiner or adjective may in such cases seem to form a constituent with the genitive-inflected noun. Thus e.g. sin fisks tallrik will appear to mean 'the plate of his fish' (rather than 'his plate of fish'), and en vanlig tidnings sida 'the page of an ordinary newspaper' (rather than 'an ordinary page from a newspaper').

Summing up, it is obvious from these examples that the quoted learners, at their current stage, do not consistently separate genitive and compound constructions. Nor have they fully acquired the \pm specific possessor criterion for making functional use of the distinction between the two constructions. From the point of view of the target language, formal and semantic-contextual criteria for interpreting the learner's utterances may come into conflict. When the 
two nouns occur in separate words, especially the $-s$ marking will function as a strong indicator of a genitive reading, whereas the equivalence of a compound formation in the target language will be the preferred reading if an $-s$ is lacking and/or the context suggests that the first noun should be understood as non-referential.

As shown in section 2.3 above, there are also cases in Swedish where noun-noun compounding and a PNP are both possible. In many such cases the learners in our study tend to favour genitive-like forms. One type is illustrated in (14), where (14a) is the occurring learner's version and (14b) and (14c) are alternative target versions. The compound version in (14b) can here be replaced by a PNP as in (14c) where the possessor noun is conceived as generic and put in the definite form. From the point of view of the target language, the learner's version is a hybrid form, most likely to be interpreted as a PNP.
a. $\quad$... den viktigaste frågan som måste lösas först är $\begin{array}{ll}\text { diskriminerings } & \text { problem. } \\ \text { discrimination-GEN } & \text { problem }\end{array}$
'... the most important issue which must be solved first is the problem of discrimination' (G3-8)
b. ... diskrimineringsproblemet. discrimination-LINKER-problem-DEF.SG
c. ... diskrimineringens problem. discrimination-DEF.SG-GEN problem

In other cases, it is possible to conceptualise a message variably, either with a specific possessor expressed with a genitive, or as a nonreferential classifying element as the first noun in a compound. (15a) is an example of such a case where the learner does not observe the distinction. (The writer is describing the page of a newspaper.)
a. Uppe $i$ sidan står
ett
sidans
nummer,
IND.ART page-
number-DEF.SG-GEN 


$\begin{array}{lllll}\text { ett } & \text { tidningens } & \text { namn } & \text { och } & \text { ett } \\ \text { IND.ART } & \text { newspaper- } & \text { name } & \text { and } & \text { IND.ART } \\ \text { datum. } & & & & \\ \text { date DEF.SG-GEN } & & & \end{array}$

Lit:: 'at the top of the page stands a the page's number, a the newspaper's name and a date' (S1-7)

b. Upptill på sidan står ett sidnummer, ett tidningsnamn och ett datum.

'... a page number, a newspaper name and a date'

c. Upptill på sidan står sidans nummer, tidningens namn och datum.

'.. the number of the page, the name of the newspaper and [the] date'

Assuming that the indefinite articles in (15a) are purposefully used by the learner, the intended message should be as in (15b), where the target language uses the compounding strategy. But it is also possible to express the 'page', 'newspaper' and 'date' as referring to specific entities, by using the genitive for the first two items and dropping the indefinite articles, as in (15c). The learner apparently conceptualises the utterance as in (15b) but uses a genitive strategy, more like (15c), for the construction.

In summary, the learners show clear tendencies to favour genitivetype constructions at the expense of compounding, both in cases where the non-referentiality of the first noun would motivate a compound and in cases where the choice between compound and PNP is optional. This is accompanied by tendencies to blur the formal distinction between a noun-noun compound and a nominal genitive construction.

\subsection{Genitives and prepositional constructions}

In connection with possessive prepositional constructions, there are two main problem areas in which the learner data show characteristic solutions, viz., (i) the relation between PNPs and prepositional con- 
structions and (ii) the choice of preposition in prepositional constructions.

In most of the cases where a possessive prepositional construction is used in Standard Swedish, it can be replaced in a more or less natural way by a PNP (as long as the possessee is thought of as definite). But there are contexts where a genitive would appear unnatural to native users of Swedish, who will prefer a locative-possessive construction instead. The learners' inclination to favour the PNP becomes apparent in such cases. Examples of this are (16) and (17), illustrating cases of LOCATION and PART-WHOLE, respectively.

(16) Det är en stor ansvar för de, som bestämmer om världens situation ...

world-DEF.SG-GEN situation

'Det är ett stort ansvar för dem som bestämmer om situationen i världen'

'It is a great responsibility for those who decide about the situation in the world' (P1-6)

(17) Det är inte lätt när lever

dagens största i mörket.

day-DEF.SG-GEN great-SUP-DEF

'Det är inte lätt när man lever största delen av dagen $i$ mörker.'

'It is not easy when you live the greatest part of the day in darkness.' (Q1-9)

As we pointed out earlier, learners show a tendency to use PNPs even with indefinite possessees. This is a further cause of underrepresentation of prepositional constructions in learners' utterances, since prepositional constructions would usually be the natural way of expressing adnominal possession in the target language in such cases. In (18) the genitive is used in a DEPICTING relation where the indefinite possessee (normal in an existential sentence) would call for a prepositional construction. 
Det finns även många människors many human-PL-GEN bildar. picture-PL

'Det finns även bilder på/av många människor.'

'There are also pictures of many persons.' (C2-7)

In section 3.2 we quoted several cases where a genitive is combined with an indefinite article or quantifier, and the possessee is obviously intended as indefinite. Again, a locative-possessive construction is a way of getting around this problem. This phenomenon occurs with various possessor-possessee relations, e.g. LOCATION as in example (11) en stor landets stad 'en stor stad på landet' 'a big city in the country' and INTERPERSONAL RELATION as in (9) många Mings vänner 'många vänner till Ming', lit.: 'many friends to Ming'.

The other main tendency in the learner data is to overgeneralise the preposition $a v$ when using a prepositional construction, thus underusing the various locative-possessive constructions. There is ample evidence of this in the corpus. It also cuts across various types of possessor-possessee relations, as the following examples show:

\section{(19) LOCATION}

Då kan det contraler prise av hela price of whole-DEF

världen.

world-DEF.SG

'Då kan det kontrollera priset i hela världen.'

'Then it can control the price in the whole world.' (C4-6)

(20) PART-WHOLE

$\begin{array}{llll}\text { en } & \text { ben } & a v & \text { stolen } \\ \text { IND.ART } & \text { leg } & \text { of } & \text { chair-DEF.SG }\end{array}$

'ett ben på stolen'

'a leg of the chair' 
(21) REPRESENTATION

en ganska lång historia $\begin{aligned} & a v \\ & \text { of }\end{aligned}$
IND.ART rather long history
deras liv
their life(-PL)
'en ganska lång historia om/över deras liv'
'a rather long history of their lives' (S1-7)

(22) INTERPERSONAL

$\begin{array}{llll}e n & v a ̈ n & a v & d e \\ \text { IND.ART } & \text { friend of }\end{array}$

'en vän till dem'

'a friend of theirs' (C1-9)

(23) CONNECTION

Hon öppenar handväska och tar

nyckelen av dörren.

key-DEF.SG of door-DEF.SG

'Hon öppnar handväskan och tar fram nyckeln till dörren.'

'She opens her handbag and takes out the key to the door.' $(\mathrm{C} 1-3)$

In the cases illustrated above, the underlying spatial sense for the target language user is one of 'location at/in/on etc.' (ex. 19 - 21) or 'direction to' (ex. 22-23). Such cases are frequent in the corpus and indicate that the learners are using $a v$ in the function of a general possessive preposition. The use of one general possessive preposition instead of a range of different spatial prepositions for different locative-possessive relations can be interpreted as a case of reductive simplification: in this way the learner avoids a variation in form which is quite subtle and bound to be difficult to master at a preadvanced stage.

However, the question arises why precisely $a v$ is chosen as such a general marker. To start with, the learners also use $a v$ regularly in such cases where it is normal usage even in the target language. These include cases for which 'direction from' is the underlying spa- 
tial sense, e.g. TRACE relations as in (24a), or ORIGINATOR relations as in (24b), as well as OBJECTS of deverbal nouns, as in (24c).
a. lukten av en afrikansk dag 'the smell of an African day' (E2-9)
b. $\quad$ klassik film av p.ex. Bresson 'klassisk film av t.ex. Bresson' 'classical film by e.g. Bresson' (G2-1)
c. Iraks annektering av Kuwait 'the annexation of Kuwait by Iraq' (G3-6)

Other important cases in this connection are PART-WHOLE relations where the nominal head is a relational noun, as in (25a-b), and SUBSET relations as in $(26 \mathrm{a}-\mathrm{b})$ :
a. $\quad$ i mitten av sidan
'in the middle of the page' (G3-7)
b. resten av dagen
'the rest of the day' (P1-5)

(26) a. en av hans fickor

'one of his pockets' (C2-10)

b. somliga av dessa myter

'some of these myths' (G2-10)

In some such cases the choice between $a v$ and a specific locativepossessive preposition is optional in the target language, depending on whether one wants to give prominence to the partiality or the locative element. This variation is possible e.g. in $i$ mitten av/på sidan 'in the middle "of/on" the page' (cf. 25a) and somliga av/bland dessa myter 'some "of/among" these myths' (cf. 26b). The fact that the choice is freer in some cases than others is likely to be a difficult point for learners. Thus, e.g. resten av dagen (ex. 25b) could not be replaced by *resten på dagen; with 'rest' the perspective of partiality prevails. In cases like these, both when variability is and is not permitted in the target language, the learners tend to use $a v$. 
The fact that there is a certain range of cases where learners can use $a v$ successfully in various possessor-possessee relations is likely to support $a v$ as an attractive candidate for use in a general possessive function in the learner language.

This is further supported by the complications involved in choosing a locative preposition. With some types of locative-possessive constructions it is far from self-evident, which spatial relation is applicable. Should, for example, 'the key that belongs to the door' (cf. ex. 23) be conceptualised as 'the key to the door' or 'the key from the door'? The former applies in Swedish, but other languages may differ; cf. e.g. Russian ključ ot dveri 'key from door:GEN'. Likewise, is it 'a leg on the chair' or 'a leg from the chair'? 'A friend to them' or 'a friend from them'? These choices are hard to foresee for a learner.

It seems then that the learners, in the need for a simple-choice solution, tend to rely on $a v$, which appears widely applicable and is found to cover various basic conceptual relations such as 'FROM' relations, origin, partiality and the like.

The use of $a v$ is also overgeneralised to NPs with nouns being used as units of measurement, which are constructed without a preposition in the target language, e.g. ett paket av cigaretter for 'ett paket cigaretter' 'a pack of cigarettes' (P1-5); ett oündligt antal av sjöar for 'ett oändligt antal sjöar' 'an infinite number of lakes' (E2-9).

We should of course also note the possible role of several of the learners' background languages in supporting a simple choice of $a v$ in the place of other prepositions (cf. Appendix). German von and Spanish and Portuguese de provide L1 models; and in particular, since all the learners in our study were acquainted with English which has great over-all similarity with Swedish, the wide use of English of in analogous cases is a possible source of influence for all our subjects.

Summarising briefly the findings in connection with prepositional constructions, we have noted two main phenomena in the learners' production: 
1. Since learners tend to favour the PNP, which becomes apparent in cases where it is either less natural or impossible in the target language, they underexploit the available prepositional constructions.

2. Learners tend to overgeneralise the preposition $a v$ when using a prepositional construction, applying it as a general possessive preposition. This strategy appears to be supported by various cases in Swedish where a construction with $a v$ is appropriate, by the complexities in the conceptualisations governing the choice of locativepossessive prepositions in Swedish, and by models in the learners' background languages.

\section{Concluding discussion}

In the preceding sections, we presented an overview of the Swedish system of adnominal possession and explored its main characteristics partly in a typological context and partly from the point of view of second language learners of Swedish who try to acquire and handle this grammatical system.

Although the grammatical domain of adnominal possession is an open-ended domain which cannot be sharply delimited, it is still possible to identify a core area of adnominal possessive constructions in a language. Among the three main types of constructions which are used to express adnominal possession in Swedish, viz. the standard possessive noun phrase (PNP), noun-noun compounds, and prepositional constructions, we identified the first one, particularly PNPs with $s$-genitives, as the unmarked, or default type, due to its simple and invariant form, its transparency, and its applicability to prototypical cases of possessive relations. Typologically, the Swedish system is characterised by the inherent definiteness of PNPs with article-possessor complementarity, and by the complex pattern of distribution between PNPs, compounding and various locativepossessive prepositional constructions.

The learners who served as subjects generally acquired the major types of Swedish possessive constructions and used them produc- 
tively. To a great extent their use of the basic types of constructions is accurate and functionally adequate from the point of view of the target language. But when it deviates from the Swedish standard norm, we can observe certain systematic patterns.

In particular, all the basic constraints that shape and differentiate the Swedish system in a language-specific way show a tendency of not being observed by the learners: PNPs are used with indefinite possessees, possessive pronouns and nominal genitives are combined with articles or other determiners, PNPs are used where the first noun is non-referential, and PNPs or prepositional constructions with $a v$ are used in cases where various locative-possessive constructions would be preferred by Swedes. These various tendencies are of course tendencies toward simplification; if they had been carried through consistently, this would have simplified the L2 system radically.

We believe that a typological viewpoint can help clarify the problems learners have with the definiteness of PNPs and articlepossessor complementarity in Swedish. A PNP is superficially a morphologically simple structure - a possessor overtly marked for the relation combines with the basic form of the head. For an outsider, since a PNP does not contain any articles, which are the grammaticalised markers for indefiniteness or definiteness par excellence, the form of a PNP simply does not signal whether it is definite or indefinite. As we suggested in section 2.6.1, the pattern of article-possessor complementarity in possessive NPs which is found in languages like Swedish and English is opposed to the pattern found e.g. in Italian according to the parameters of ECONOMY vs. EXPLICITNESS in the expression of definiteness. It is thus difficult to say a priori which of the cross-linguistically attested structures for possessive NPs is more marked than the other one, or which one will be most difficult to acquire - the "economic" one, à la Swedish or English, or the "explicit" one à la Italian. Both have advantages and disadvantages. For instance, explicit structures seem to be generally favoured at early stages in L2 acquisition. Also, economy can be understood in various ways. Thus, structures showing article-possessor incompatibility are, of course, shorter - here economy refers to 
SYNTAGMATIC ECONOMY, which primarily has to do with production of utterances in real time.

Somewhat paradoxically, however, the more explicit structures can also be considered as more economic in other respects, namely, from the point of view of PARADIGMATIC ECONOMY. Thus, whereas possessive NPs allowing articles can express the definiteness opposition basically by means of one and the same construction, possessive NPs showing article-possessor complementarity have to alternate with constructions of a different type in those relatively rare cases where the whole NP is not definite. Cf. il/un bel vestito di Anna and Anna's beautiful dress vs. a beautiful dress of Anna's.

It is also important to consider the PNP constructions in relation to the whole system of definiteness marking in the language. The Swedish system shows a high degree of complexity with its different patterns of marking definiteness, a system which can be termed PARADIGMATICALLY NON-ECONOMIC. Against this background, a PNP showing article-possessor complementarity implies a higher number of the different construction patterns to memorise.

Here it is instructive to compare Swedish and English. Even though article-possessor complementarity has arisen due to the same historical process (with a new definite article going through the grammaticalisation process, spreading to new contexts, but not all the way, cf. Haspelmath 1999b: 237-239), the concrete manifestations of this pattern and its place in the system are quite different in the two languages. Thus, English has a fairly uniform and PARADIGMATICALLY ECONOMIC system of marking (in)definiteness by means of the first element in a NP - an article, a demonstrative, an indefinite or negative quantifier, a possessor etc. The articles have a fairly standard form, and there are normally no problems in identifying the basic form of a noun. It would be instructive to study whether L2 learners of English show deviations from the article-possessor complementarity pattern in English comparable to those reported in our study.

The tendency for the learners to disregard the various characteristic properties of the target system, such as PNP definiteness, \pm specific possessor, and the Swedish preference for locative- 
possessive constructions, have the combined effect that the use of some types of constructions gets extended and other types get underused in the learners' production, as compared to the target usage. Thus the learners are seen to favour PNPs and especially the $s$ genitive of nouns at the cost of noun-noun compounds and prepositional constructions. With prepositional constructions they extend the use of a common possessive $a v$ and avoid the more specific locativepossessive conceptualisations.

This means that the learners not only tend to simplify the L2 system by ignoring distinctions and reducing the use of alternants for something which they perceive as the same meaning (Andersen's "One-to-One Principle", 1984, 1990). What is important, they simplify in particular directions.

By extending the $s$-genitive, the learners are seen to favour precisely the type of construction that we have identified as unmarked on formal and semantic grounds. It is invariant in form, transparent, and more salient than compounding. This makes it easy to handle from a formal point of view. Furthermore, it is a construction that is regularly used in Swedish in all the prototypical cases of possession that we identified above. If learners are inclined to orient themselves to what they can perceive as the "proper", or prototypical way of expressing possessive relations, then it appears natural that they will tend to opt for the genitive construction in Swedish, given the uses that the genitive is bound to have in the learners' target language input.

As for the constructions with agreeing possessive pronouns, they may be said to be both problematic and unproblematic for the learners. The restriction of these constructions to definite NPs and the incompatibility of the possessive pronouns with articles and other determiners is indeed a problem for learners, as we have seen. But on the other hand, pronominal constructions do not seem to be underused. One obvious reason for this is that they have few natural substitutes. Compounding is not a realistic option; PNPs generally are not found to be replaced by compounds - and if compounding were to replace pronominal constructions, what would the first part of the compound be? The contexts where prepositional constructions 
could replace pronominal ones are few in practice. A further circumstance is that, like genitives of nouns, the pronominal constructions usually apply in highly prototypical cases of possession: with definite, human possessors, with legal possession, body-parts, kinship etc. Hence the same orientation towards the prototypical as we argumented for above should apply to pronominal as well as to genitive constructions.

The learners' handling of prepositional possessive constructions appears to be governed by at least in part the same principles. The underexploitation of prepositional variants applies to locativepossessive constructions, and not so much to constructions with av. $A v$ is adequately used in numerous cases where native Swedes would use it, but also extended to cases where other prepositions would be used. In general, we could expect adnominal prepositional constructions to be relatively easy for learners to manage since they represent an analytic and salient type of construction. To master the differentiated and subtle nature of the Swedish system of locative-possessive variants is on the other hand a complex task. Making extended use of $a v$ as a general, or default possessive preposition means widening the domain of invariance in this area. The choice of $a v$ is supported by the fact that it already has a rather wide applicability in the target language (which can be assumed to be reflected in the learners' Swedish input). Although $a v$ does not qualify as a prototypical possessive marker according to our criteria (it is not used with LEGAL POSSESSION, and not typically with BODY-PART or KINSHIP relations), it still applies to a range of rather kindred types of relations in the area of partiality-subset-origin etc.

It is interesting to view the learner's acquisitional task in the context of (diachronic-typological) grammaticalisation. First of all, the fact that possessive $a v$ in Swedish represents a case of grammaticalisation from the underlying spatial 'FROM' sense, and that this spatial sense is still more or less transparent, constitutes a parallel to the nearest counterparts in English and some of the other background languages (Engl. of, Ger. von, Sp. and Por. de). (Note that all our subjects were acquainted with the use of of in English.) This is a case in point for the set of L2 operating principles that Andersen (1983, 
1990) has brought together as the "Transfer to Somewhere Principle":

A grammatical form or structure will occur consistently and to a significant extent in the interlanguage as a result of transfer if and only if (1) natural acquisitional principles are consistent with the $\mathrm{Ll}$ structure or (2) there already exists within the $\mathrm{L} 2$ input the potential for (mis-)generalisation from the input to produce the same form or structure. Furthermore, in such transfer preference is given in the resulting interlanguage to free, invariant, functionally simple morphemes which are congruent with the L1 and L2 (or there is conguence between the $\mathrm{Ll}$ and natural acquisition processes) and [to] morphemes [which] occur frequently in the L1 and/or the L2. (Andersen 1983: 182 , italics in original.)

We might add that, as has become clear in modern $\mathrm{L} 3$ acquisition research, prior L2s may also, besides L1, have a substantial influence on learners' interlanguages. (For some discussion of this point and further references, cf. Hammarberg 2001.) This has relevance for English of constructions in the present connection.

The fact that the grammaticalisation of a 'FROM' preposition has gone much further in the background languages and taken over a wider domain than in the case of Swedish $a v$, has at least two further implications in the present context. One is that the wider applicability of of, von, de supports widened use of $a v$ by the learners. Andersen's conditions (1) and (2) are both fulfilled. The other implication has to do with the extent to which grammaticalisation has taken place in the language. Languages like English, German, Spanish and Portuguese have undergone a development where one spatial preposition has been generalised in an abstract role and taken over a very wide domain of adnominal relations including those of prototypical possession. Swedish appears to be midway in such a process, showing a state with several locative-possessive constructions, numerous cases of variation and fine distinctions, and on the whole a relatively strong role still for the locative element. Particularly, the process has not fully involved the prototypical cases of possessive relations. As we touched upon earlier, such transitional systems often tend to be com- 
plex. This points to a type of positive connection between grammaticalisation and acquisition. On the one hand, there is the learner's need for a simple and dependable way of expressing an abstract notion such as possession. The task in this case is obviously complicated by the fact that the domain of possession is so complex and fuzzy-edged. On the other hand, the existence of highly grammaticalised forms of encoding in the learner's input and background languages provides a model for what turns out to be an attractive interim solution for the learner.

\section{Appendix - Concise information on the encoding of adnominal possession in the first languages of the learners in the ASU Cor- pus}

English expresses possession by (i) preposed non-agreeing possessive pronouns, (ii) preposed nouns with 's-genitives, (iii) noun-noun compounds, and (iv) postposed prepositional modifiers mostly with of, but also (v) to a lesser extent than Swedish, with locative-possessive constructions. The distribution of genitives and compounds depends on \pm specificity of the modifying noun; genitives and of constructions are partly interchangeable and partly complementary, depending on a complicated system of factors. Possessive NPs type (i) and (ii) are inherently definite, with article-possessor complementarity. Similarities and differences compared to the Swedish system will be apparent in the examples throughout this article.

German expresses possession by (i) preposed agreeing possessive pronouns, (ii) possessor nouns in the genitive, usually postposed but preferably preposed in the case of personal proper names, (iii) noun-noun compounds, (iv) postposed prepositional modifiers mostly with von, but also (v) to some extent with locativepossessive constructions. The distribution of genitives and compounds depends on \pm specificity of the modifying noun, much as in Swedish; genitives and von constructions are partly interchangeable, subject to stylistic factors, genitive being used more in Standard German than in Standard Swedish. Possessive NPs with preposed genitives or pronominal possessors are inherently definite with articlepossessor complementarity, but those with postposed genitives are not.

Spanish expresses possession by (i) agreeing possessive pronouns, pre- or postposed, and (ii) postposed prepositional modifiers with de, which are used for a wide variety of relations. No genitive inflection of nouns. Only very limited use of noun-noun compounding. NPs with preposed possessive pronouns are inherently 
definite and do not combine with definite articles or determiners; NPs with postposed possessive pronouns may be definite or indefinite and do combine with articles or determiners.

Portuguese expresses possession by (i) preposed and postposed agreeing possessive pronouns, and (ii) postposed prepositional modifiers with de, which are used for a wide variety of relations. No genitive inflection of nouns. Only limited use of noun-noun compounding. Possessive NPs type (i) are not necessarily definite. Possessive pronouns combine with definite and indefinite articles or determiners.

Modern Greek expresses possession by (i) postposed enclitic non-agreeing genitives of pronouns, (ii) pre- or postposed possessor nouns in the genitive, (iii) nounnoun compounds, and (iv) postposed prepositional modifiers with apó 'from' for a range of non-prototypical relations of possession, to some extent alternating with genitives. Possessive NPs type (i) and (ii) are most often but not always definite; possessors are combined with definite or indefinite articles.

Polish expresses possession by (i) preposed (partly agreeing) possessive pronouns, (ii) preposed agreeing possessive adjectives, (iii) preposed agreeing relational adjectives, and (iv) postposed nouns in the genitive. No significant use of noun-noun compounds or possessive prepositional constructions. Adjectives of type (ii) are derived from proper names or some other personal referents such as kin terms. Types (ii) and (iv) are used with specific possessors, whereas type (iii) is not. Since definiteness is not grammaticalised and articles are not used, article-possessor combinability is not an issue.

Chinese marks possessors by the general relational postposition de which can govern both pronouns and full NPs. The possessor then precedes the possessee. Chinese has a rich system of various types of compounding, one of which is nounnoun compounding with the first noun qualifying the second. Chinese is on the whole an isolating language, so there is no genitive inflection or pronominal agreement, nor is there any grammaticalised definiteness category.

\section{Notes}

1. Definite possessors constitute $65 \%$ NPs with preposed genitive attributes in Pitkänen's (1979: 70) corpus covering Swedish texts from the $17^{\text {th }}-20^{\text {th }}$ centuries. For modern texts this figure might be even higher (Kari Fraurud p.c.).

2. The structure of Swedish NPs, in particular their definiteness marking has received much attention, among other things, within various syntactic theories. 
See e.g. Börjars 1994, Cooper 1984, Delsing 1993, Holmberg (ed.) 1992, Perridon 1989.

3. A useful notion for describing the choice of prepositional attributes is valency, accepted and elaborated in various theories (and also incorporated into Langacker's Cognitive Grammar, cf. Taylor 1996: 93-96 for the usefulness of this notion in the interpretation of English - 's-genitives). For an attempt to apply this notion to the system of prepositional attributes in Swedish cf. Pitkänen (1979). A related notion is Pustejovsky's (1991) notion of qualia structure.

\section{References}

Andersen, Roger W.

1983 Transfer to somewhere. In: Susan Gass and Larry Selinker (eds.), Language Transfer in Language Learning, 177-201. Rowley MA: Newbury House.

Andersen, Roger W.

1984 The one to one principle in interlanguage construction. Language Learning 34: 77-95.

Andersen, Roger W.

1990 Models, processes, principles and strategies: Second language acquisition inside and outside the classroom. In: Bill VanPatten and James F. Lee (eds.), Second Language Acquisition/Foreign Language Teaching, 45-68. Clevedon/Philadelphia: Multilingual Matters.

Axelsson, Monica

1994 Noun phrase development in Swedish as a second language. Ph.D. dissertation. Stockholm: Stockholm University, Centre for Research on Bilingualism.

Börjars, Kersti

1994 Swedish double determination in a European typological perspective. Nordic Journal of Linguistics 17: 219-252.

Clahsen, Harald, Jürgen M. Meisel, and Manfred Pienemann

1983 Deutsch als Zweitsprache: der Spracherwerb ausländischer Arbeiter. Tübingen: Gunter Narr.

Cooper, Robin

1984 Svenska nominalfraser och kontext-fri grammatik. [Swedish noun phrases and context-free grammar.] Nordic Journal of Linguistics 7: 115-144.

Croft, William

1990 Typology and Universals. Cambridge: Cambridge University Press. 
Delsing, Lars-Olof

1993 The internal structure of noun phrases in the Scandinavian Languages. Ph.D. dissertation. Lund University, Dept. of Scandinavian Languages.

Dittmar, Norbert

1992 Grammaticalization in second language acquisition: introduction. Studies in Second Language Acquisition 14: 249-257.

Eckman, Fred R.

1977 Markedness and the contrastive analysis hypothesis. Language Learning 27: 315-330.

Eckman, Fred R.

1996 A functional-typological approach to second language acquisition theory. In: William C. Ritchie and Tej K. Bhatia (eds.), Handbook of Second Language Acquisition, 195-211. San Diego: Academic Press.

Fraurud, Kari

1990 Definiteness and the processing of noun phrases in natural discourse. Journal of Semantics 7: 395-433.

Giacalone Ramat, Anna

1992 Grammaticalization processes in the area of temporal and modal relations. Studies in Second Language Acquisition 14: 297-322.

Giorgi, Alessandra, and Giuseppe Longobardi

1991 The Syntax of Noun Phrases: Configuration, Parameters and Empty Categories. Cambridge: Cambridge University Press.

Greenberg, Joseph $\mathrm{H}$.

1966 Language Universals. The Hague: Mouton.

Haiman, John

1985 Natural Syntax. Cambridge: Cambridge University Press.

Hammarberg, Björn

1996 Examining the processability theory: The case of adjective agreement in L2 Swedish. In: Eric Kellerman, Bert Weltens and Theo Bongaerts (eds.), EUROSLA 6, A Selection of Papers, 75-88. Amsterdam: ANéLA.

Hammarberg, Björn

1999 Manual of the ASU Corpus, a longitudinal text corpus of adult learner Swedish with a corresponding part from native Swedes. Stockholm University, Department of Linguistics.

Hammarberg, Björn

2000

A polyfunctional word in native usage and L2 acquisition: The Swedish neutral pronoun "det". In: Johan Falk, Gunnar Magnusson, Gunnel Melchers and Barbro Nilsson (eds.), Kontraster $i$ språk/Contrasts in Languages, 103-129. (Stockholm Studies in 
Modern Philology 12.) Stockholm: Almqvist \& Wiksell International.

Hammarberg, Björn

2001 Roles of L1 and L2 in L3 production and acquisition. In: Jasone Cenoz, Britta Hufeisen and Ulrike Jessner (eds.), Cross-Linguistic Influence in L3 Acquisition: Psycholinguistic Perspectives, 21-41. Clevedon/Philadelphia: Multilingual Matters.

Hammarberg, Björn, and Åke Viberg

1977 The place-holder constraint, language typology, and the teaching of Swedish to immigrants. Studia Linguistica 31: 106-163.

Haspelmath, Martin

1999a External possession in a European areal perspective. In: Doris L. Payne and Immanuel Barshi (eds.), External Possession, 109-135. Amsterdam/Philadelphia: John Benjamins.

Haspelmath, Martin

1999b. Explaining article-possessor complementarity: Economic motivation in noun phrase syntax. Language 75: 227-243.

Hawkins, John

1978 Definiteness and Indefiniteness: A Study in Reference and Grammaticality Prediction. London: Croom Helm.

Hawkins, John

1991 On (in)definite articles: Implicatures and (un)grammaticality prediction. Journal of Linguistics 27: 405-442.

Heine, Bernd

1997 Possession. Cognitive Sources, Forces, and Grammaticalization. Cambridge: Cambridge University Press.

Holmberg, Anders (ed.)

1992 Papers from the Workshop on the Scandinavian Noun Phrase. University of Umeå, Department of General Linguistics, report 32.

Hyltenstam, Kenneth

1984 The use of typological markedness conditions as predictors in second language acquisition: The case of pronominal copies in relative clauses. In: Roger W. Andersen (ed.), Second Languages, 3958. New York: Newbury House.

Hyltenstam, Kenneth

1986 Markedness, language universals, language typology, and second language acquisition. In: Carol W. Pfaff (ed.), First and Second Language Acquisition Processes, 55-78. New York: Newbury House.

Klein, Wolfgang, and Norbert Dittmar

1979 Developing Grammars: The Acquisition of German Syntax by Foreign Workers. Berlin/New York: Springer-Verlag. 
Klein, Wolfgang, and Clive Perdue

1997 The Basic Variety (or: Couldn't natural languages be much simpler?). Second Language Research 13: 301-347.

Koptjevskaja-Tamm, Maria

2001 Adnominal possession. In: Martin Haspelmath and Ekkehard König (eds.), Handbuch der Typologie. Berlin: Mouton de Gruyter.

Koptjevskaja-Tamm, Maria

forthc. a Genitives and possessive NPs in the languages of Europe. To appear in: Frans Plank (ed.), The Noun Phrase in the Languages of Europe. Berlin: Mouton de Gruyter.

Koptjevskaja-Tamm, Maria

forthc. b "A woman of sin", "a man of duty" and "a hell of a mess": Nondeterminer genitives in Swedish. To appear in: Frans Plank (ed.), The Noun Phrase in the Languages of Europe. Berlin: Mouton de Gruyter.

Lakoff, George, and Mark Johnson

1980 Metaphors We Live By. Chicago/London: The University of Chicago Press.

Langacker, Ronald W.

1991 Foundations of Cognitive Grammar. Vol.II. Stanford: Stanford University Press.

Langacker, Ronald W

1995 Possession and possessive constructions. In: John R. Taylor and Robert E. MacLaury (eds.), Language and the Cognitive Construal

Lehmann, Christian of the World, 51-79. Berlin/New York: Mouton de Gruyter.

1998

Lyly, Erika

1996 En bild av Picasso eller en bild på Picasso? [A picture "av" Picasso or a picture "på" Picasso?]. In: Språket lever! Festskrift till Margareta Westman den 27 mars 1996, 202-207. Stockholm: Svenska språknämnden.

Lyons, Christofer

1986 The syntax of English genitive constructions. Journal of Linguistics 22: 123-143.

Mobärg, Mats

1998

Norde, Muriel

1997
Om gestalttext. [On gestalt-text.] Språkvård 1-1998: 10-14.

The history of the genitive in Swedish: A case study in degrammaticalization. Doctoral dissertation. Amsterdam: University of Amsterdam. 


\section{Björn Hammarberg and Maria Koptjevskaja-Tamm}

Perdue, Clive (ed.)

1993 Adult Language Acquisition: Cross-Linguistic Perspectives. Vol. 1-2. Cambridge: Cambridge University Press.

Perdue, Clive, and Wolfgang Klein

1992 Why does the production of some learners not grammaticalize?

Studies in Second Language Acquisition 14: 259-272.

Perridon, Harry Christian Bernard

1989 Reference, Definiteness and the Noun Phrase in Swedish. Academic Proefschrift, Universiteit van Amsterdam.

Pfaff, Carol W.

1992 The issue of grammaticalization in early German second language.

Studies in Second Language Acquisition 14: 273-296.

Pitkänen, Antti

1979 Binominala genitiviska hypotagmer i yngre svenska. [Binominal genitive hypotagms in younger Swedish.] (Skrifter utgivna av svenska litteratursällskapet i Finland 484.) Doctoral dissertation, Helsinki.

Plank, Frans

1995 (Re-)Introducing Suffixaufnahme. In Frans Plank (ed.), Double Case. Agreement by Suffixaufnahme, 3-110. New York/Oxford: Oxford University Press.

Pustejovsky, James

1991 The generative lexicon. Computational Linguistics 17: 409-441.

Seiler, Hansjakob

1983 Possession as an Operational Dimension of Language. Tübingen: Narr.

Serzisko, Fritz

1984 Der Ausdruck der Possessivität im Somali. (Continuum Schriftenreihe zur Linguistik 1.) Tübingen: Narr.

Skiba, Romuald, and Norbert Dittmar

1992 Pragmatic, semantic, and syntactic constraints and grammaticalization: A longitudinal perspective. Studies in Second Language Acquisition 14: 323-349.

Stolz, Thomas with Sabine Gorsemann

forthc. Island possessions: Pronominal possession in Faroese and the parameters of alienability/inalienability.

Taylor, John R.

1996 Possessives in English. An Exploration in Cognitive Grammar. Oxford: Clarendon Press. 
Teleman, Ulf, Staffan Hellberg, and Erik Andersson

2000 Svenska Akademiens grammatik, Vol. 3: Fraser. [Grammar of the Swedish Academy. Vol. 3. Phrases.] Stockholm: Svenska Akademien \& Norstedts ordbok.

Ultan, Russell

1978 Towards a typology of substantival possession. In: Joseph Greenberg (ed.), Universals of Human Language, Vol. 4: Syntax, 11-50. Stanford: Stanford University Press.

Wijk-Andersson, Elsie

1993

Bestämda nominalfraser $\mathrm{i}$ inlärarsvenska. [Definite noun phrases in learner Swedish.] In: Anne Golden and Anne Hvenekilde (eds.), Nordens språk som andrespråk, 191-197. Oslo: University of Oslo, Department of Linguistics. 
Brought to you by | Stockholm University Library

Authenticated

Download Date | 7/10/19 11:18 AM 